\title{
Research on the Influence of Village Carders on the Standardized Management System of Village-Level Affairs - Based on the Investigation and Analysis of District L, Y City, Shandong Province, China
}

\author{
Li-Wei Xing ${ }^{1} \&$ Ying Duan ${ }^{1}$ \\ ${ }^{1}$ Shandong Technology and Business University, Yantai, Shandong, China \\ Correspondence: Li-Wei Xing, Shandong Technology and Business University, Yantai, Shandong, China. E-mail: \\ 749960435@qq.com
}

Received: March 14, 2021 Accepted: April 26, 2021 Online Published: April 28, 2021

doi:10.5539/par.v10n2p1 URL: http://dx.doi.org/10.5539/par.v10n2p1

\begin{abstract}
Chinese anti-corruption struggle has achieved phased victory, the national corruption governance center has gradually moved down, and the issue of "micro-corruption" of village cadres has attracted widespread attention from the political, practical and academic circles. The standardized management system of village-level affairs is promoted and implemented nationwide as an institutional arrangement for regulating the power of village cadres and combating corruption. However, in the actual implementation process, there are problems such as passive implementation and even resistance to implementation by village cadres. The study took the L District of Y City, Shandong Province as an example, and found that the village cadres did not implement the corresponding standardized management system. The factors affecting the implementation of the standardized management system of the village cadres were investigated from the three-dimensional perspective of motivation, ability, and pressure, and then reasonable policy recommendations were put forward. Aims to give better play to the effectiveness of standardized systems.
\end{abstract}

Keywords: standardization, system, village cadre

\section{Introduction}

Irregular operation of power is an important source of corruption, The Chinese government has launched a series of policies and measures to regulate the operation of power and punish corruption The phenomenon of "great corruption" has been effectively curbed. On the basis of consolidating the staged victories in the anti-corruption struggle in the early stage, the corruption governance center has gradually moved downwards, and the anticorruption work has advanced in depth. The issue of "micro-corruption" of village cadres has begun to receive extensive attention from the political, practical and academic circles (Yu Yajie \& Chen Wenquan, 2018).

Corruption incidents occur frequently in rural areas, it is urgent to reverse the momentum of rural corruption. Rural corruption is extremely secretive and destructive. The power held by village cadres seems to be small, but it is closely related to farmers' daily lives. The alienation of rural power directly harms farmers' vital interests. Standardizing the use of power by village cadres is effective in controlling rural corruption and enhancing farmers' trust. Sense and happiness are essential. Village cadres are indispensable for the steady implementation of rural policies, rural development, adjustments, and changes also require active responses from village cadres. Therefore, under the background of the new era, it is extremely critical to standardize the management of village-level affairs and build an efficient and clean team of village cadres (Wang Sheng, 2020).

In the face of the above-mentioned practical needs and national strategic arrangements, District L of Y City, Shandong Province sorted out village-level affairs one by one, clarified the implementation entities of various village-level affairs, refined the handling procedures, agreed on time limits, and strived to standardize and standardize village-level affairs. Standardize processing, and issue a compilation manual of standardized management system for village affairs in L District in July 2020. The contents of the manual mainly include: village-level organization working rules, rural collective fund asset resource management methods, village-level major issues decision-making methods, and village-level odd-work and lost-work subsidy management methods. 
The content is very specific and detailed. However, in the field investigation, it was found that the implementation effect of the standardized management system of village affairs was not good, and the working rules and management methods were on paper, which did not play a role in regulating the power of village cadres.

\section{Research Methods and Data Sources}

Although the main body of the implementation of the standardized management system of village-level affairs is the village cadres, the foothold and audience of the system are the vast number of villagers, so it is very important to understand the current status of the implementation of the system to understand the attitude of the villagers to the standardized management system of village-level affairs. The implementation of the standardized management system of village affairs in L District was investigated by issuing questionnaires. A total of 100 questionnaires were issued and 87 valid questionnaires were recovered. The basic content of the questionnaire includes information such as the gender, age, and education level of the surveyor. The core issues include: (1) Villagers' satisfaction with the work of village cadres before and after the implementation of the standardized management system for village-level affairs (2) Whether the village cadres can implement the standardized management system for village-level affairs. The villagers scored according to the daily work efficiency and work attitude of the cadres of the "village committees and two committees" (Figure 1). Through the scoring results, they can understand the villagers' satisfaction with the village cadres' work, and compare the scores before and after the implementation of the system. The changes in the score can directly reflect the operation of the system and the actual effect.

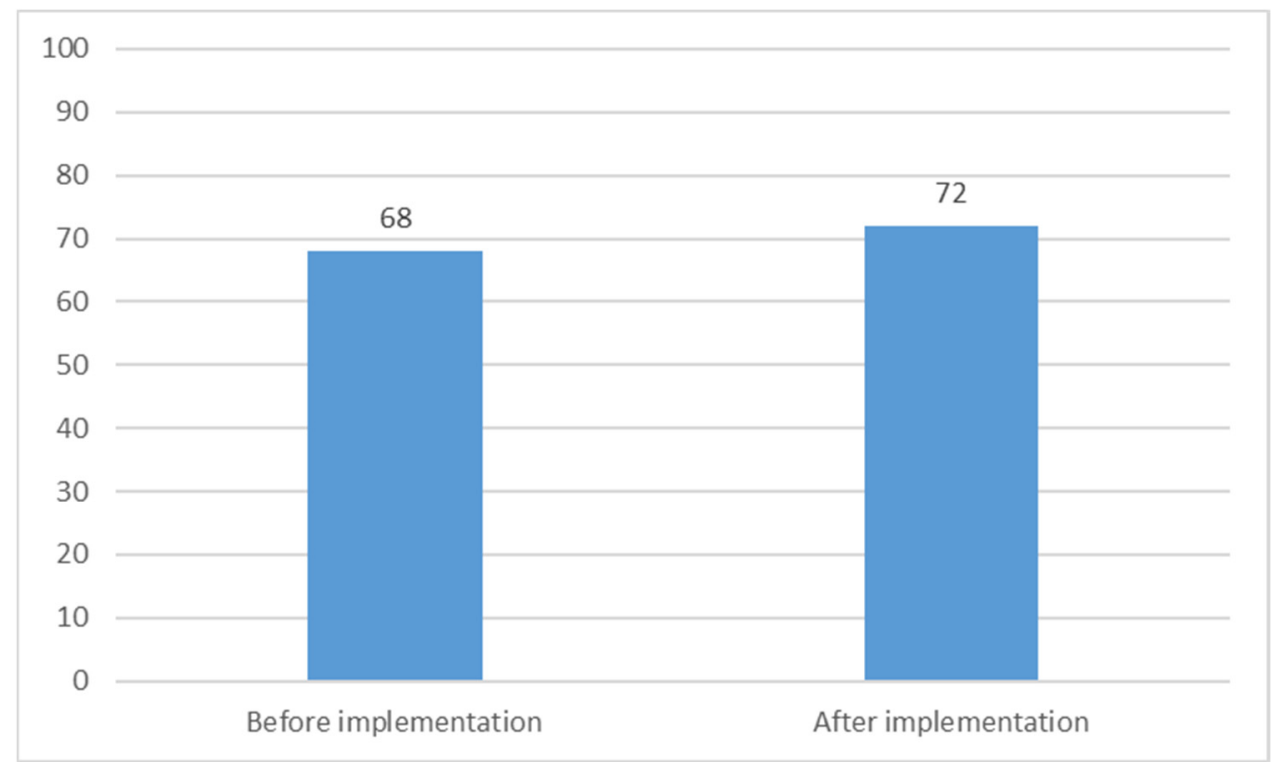

Figure 1. Villagers rate the work of village cadres before and after the implementation of the standardized management system for village affairs

The above chart shows that after the implementation of the standardized management system for village-level affairs, villagers' satisfaction with the work of "village two committees" cadres has increased slightly, and the evaluation score has increased from 68 to 72, but overall the increase is small, and the increase rate About 5.9\%, the system effect is not obvious.

Based on the villagers' inherent understanding of the standardized management system for village-level affairs and the author's objective introduction to the system, an investigation was conducted on whether the villagers believed that the village cadres implemented the standardized management system for village-level affairs. The problem is designed as: whether the village cadres can implement the standardized management system of village-level affairs. There are four options: "Not implemented", "Occasionally implemented", "Often implemented", "Strictly implemented". The specific results are shown in the figure below (Figure 2). 


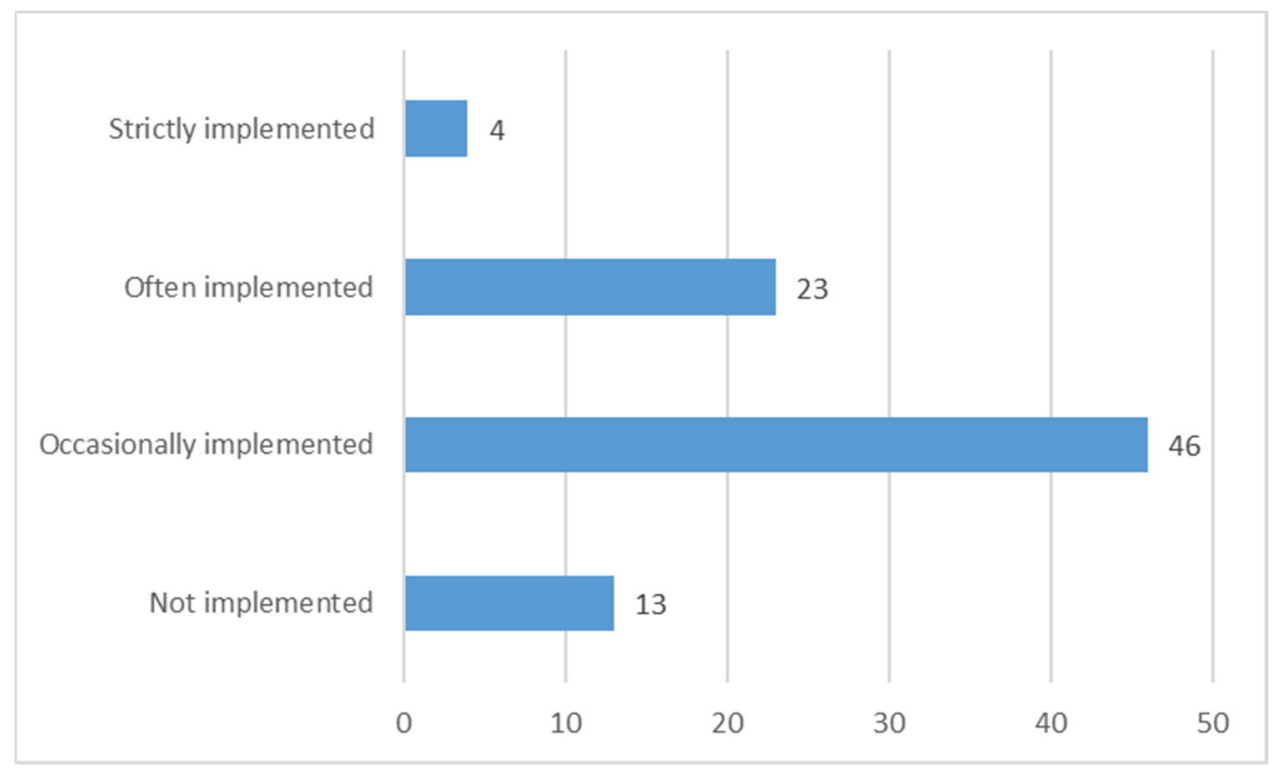

Figure 2. Villagers evaluate whether the village cadres can implement the standardized management system of village-level affairs

It can be seen that most villagers believe that the village cadres cannot implement the standardized management system. It takes time to release the effect of the system, but the survey results reflect to some extent that the village cadres have not implemented the standardized management system of village-level affairs, causing the system to deviate from the expected effect and the system implementation is in a certain dilemma. What factors caused the village cadres to passively implement or even resist the implementation of the standardized management system? Starting from the analysis of the influencing factors, the thesis puts forward policy recommendations to improve the implementation of the standardized management system of village affairs.

\section{Finding}

In response to the above-mentioned system implementation dilemma, the article explores the factors affecting the implementation of the standardized management system of village-level affairs from the three dimensions of the motivation, ability, and pressure of the village cadres, and clears the barriers in the process of institutionalization.

\subsection{Motivation: Insufficient Enthusiasm of Village Cadres}

During the interview with village officials, it was found that village officials were generally not very enthusiastic about implementing the standardized management system of village-level affairs. This situation was mainly due to the following reasons: First, rural areas are typical "weak rules" areas, and rural areas lack rigid institutional constraints (Sun Qionghuan, 2017). Some village cadres make decisions based on experience, and they have formed path dependence for a long time, and instinctively reject standardized management systems. Second, the restriction on power by the system reduces the opportunity for village cadres to obtain political benefits from rural affairs. The standardized power operation mechanism will reduce the profit space for village cadres. In this case, village cadres will inevitably implement the standardized management system passively. Third, the standardized management system of village-level affairs increases the workload of village cadres. The advantages of standardization and standardized management of rural affairs are obvious, but it will invisibly increase the work pressure of village cadres. Some matters that village cadres can make decisions by themselves now need to consult higher-level departments or meet to discuss. In addition, during the investigation, the author learned that the salary of general village cadres is lower than the income earned by migrant workers. Under the condition of mismatch between economic income and responsibility, the negative emotions generated by village cadres will cause the effect of the system to be greatly reduced.

\subsection{Ability: The Village Cadres Lack Ability}

The lack of ability of village cadres is mainly reflected in two aspects. On the one hand, the concept and consciousness are backward and the ability to interpret the system is not strong. Some village cadres are older, with relatively outdated and backward concepts, and think that they are the "masters" of the village when they are elected as village cadres, and they are free from system constraints and lack system awareness and service 
awareness. One-sided understanding of the standardized management system, selection and implementation of the management system, is conducive to the active implementation of their own policies and regulations, and the rest choose to avoid. On the other hand, the education level of village cadres is not high. Among the seven village cadres interviewed, only two have received high school education or above. The low level of education leads to a low level of policy theory for village cadres, and they cannot truly understand the core of the standardized management system. Therefore, it is difficult to resolutely implement corresponding regulations in rural work practices.

\subsection{Pressure: Lack of Supervision System}

The lack of a supervision system is the main reason for the inadequate implementation of the standardized management system for village-level affairs. Due to the lack of the rural supervision system and the lack of supervision and punishment methods in the system, the village cadres have not been given enough pressure to implement the system. On the one hand, there is a lack of self-monitoring by villagers. The countryside does not belong to the grassroots political power in the traditional sense. The villagers committee is an autonomous organization of villagers. Therefore, the villagers' supervision of the village committee cadres is a self-supervision method. During the investigation, it was found that some villagers were unaware of the implementation of a standardized management system for village-level affairs in the village, and village cadres did not tell the villagers, and village cadres still handled daily affairs according to the old method. Some villagers are aware of the implementation of a standardized management system for village-level affairs, but the village cadres do not implement it. Due to the lack of corresponding disciplinary measures, villagers often report to the township government without substantive results. Moreover, due to the existence of rural clan forces, farmers are afraid of being isolated from their own long-term interests. On the other hand, there is a lack of supervision by the township government. The villager autonomy system is an arrangement of the rural grassroots democratic political system in China, and village committee cadres have greater administrative discretion. Although in some areas, village cadres are included in the government's civil servant system for management, most of the village cadres do not belong to the government's civil servant system, and are only "agents" of the country in rural areas. In this case, the supervision of the township government is often ineffective, and the rural power supervision system has not been completed. The limited staff of the township government is also a real problem, so there is a lack of effective supervision from the township government. In this case, the supervision of the township government is often ineffective, and the rural power supervision system has not been completed. The limited staff of the township government is also a real problem, so there is a lack of effective supervision from the township government (Tian Hong, 2017).

\section{Advice}

\subsection{Strengthen System Publicity and Training, Enhance Village Cadres'Sense of Responsibility and Identity, and Improve the Main Body's Ability to Execute}

As the main responsible department, the township government should carry out various presentations on the standardized management system for village-level affairs, systematically and thoroughly explain the important practical significance of the implementation of the system, and hold regular symposiums to respond to the doubts of the village cadres, and enhance the sense of responsibility and recognition of the village cadres in a subtle way. sense. Regarding the specific implementation content and steps involved in the standardized management of village-level affairs, special and concentrated training will be given to village officials to solve the difficulties encountered in the implementation of the system in a timely manner, learn from the experience of advanced regions, and find out that they can complement their shortcomings and improve village officials. Execution ability to ensure the implementation of the system.

\subsection{Effectively Improve the Treatment of Village Cadres and Mobilize the Enthusiasm of Village Cadres in Their Work}

From the survey and practice in many places, the low salary of village cadres is a common phenomenon in rural society, and economic pressure may turn into resistance in work. In some areas, village cadres engage in second occupations privately in order to increase their income. They cannot concentrate all their energy on village affairs, and their economically disadvantaged position is difficult to convince the villagers of the village, and they doubt the identity of the village cadres as the "leader" in rural development. At the same time, the standardized management system of village-level affairs has objectively increased the workload of village cadres, improved the treatment of village cadres, and it is necessary to mobilize the enthusiasm of village cadres. On the one hand, it is necessary to improve the daily salary standard of village cadres, improve the social security mechanism for village cadres, relieve the pressure of village cadres' survival and worries for the future, and mobilize the enthusiasm of 
village cadres. On the other hand, it is necessary to scientifically establish a performance reward mechanism and a village cadre evaluation mechanism, link the evaluation system of the village cadres' implementation of the standardized management system of village-level affairs with the rewarding performance, and provide clear rewards and punishments, and encourage village cadres to implement the system from the material level.

\subsection{Attract High-Quality Talents back to Their Hometowns and Strengthen Rural Talent Reserves}

No matter how good the system is designed and arranged, the key to success or failure lies in the person who executes it. Therefore, talent is the first element and the most valuable asset in the countryside. Taking District L as an example, the district government has introduced a number of preferential policies for college students to work in their hometowns and support policies for professional and skilled talents, which have achieved certain results. In terms of actual results, the introduced high-quality talent awareness concept is more advanced, with a strong sense of rules and service awareness. It not only resolutely implements the standardized management system of village-level affairs, but also actively supports the implementation of various national policies in rural areas. The introduced talents are mainly young and middle-aged, which optimizes the age structure of village cadres and enhances the overall vitality of the village cadre group. In the next step of rural work, the government should introduce more talent introduction and support policies, take multiple measures to attract college students to work in their hometowns, retain the introduced talents, and strengthen the rural talent pool (Pu Shi \& Sun Wenying, 2018).

\subsection{Establish a Responsibility List System, and Multiple Entities to Build a Supervision System}

The standardized management system of village-level affairs sorts out village-level affairs. In essence, it clarifies the powers held by village cadres, but seldom mentions the responsibilities of village cadres. According to the principle that power must have responsibilities and powers and responsibilities must be equal, it is necessary to establish a responsibility list system for village cadres to ensure the effective operation of the standardized management system for village-level affairs, so that village cadres do not want to violate the existing system, nor dare to violate the existing system.

\section{Conclusion}

From the theoretical level, this study consummates the rural governance grass-roots power standard operation research, from the village cadre angle studies the standardized management system of village affairs is a new research dimension, puts forward the policy suggestion on the basis of the analysis influence factor, It has certain guiding significance to perfect the study of rural governance grass-roots power standard operation. Is to enrich the current social governance in the "micro-governance" research. The standardized management system of village affairs as a good system to restrict and supervise "micro-power ", will play an active role in curbing the corruption of village cadres. This paper deeply studies the standardized management system of village affairs, shifts the relevant research angle from macro to micro in social governance, and enriches the research of "micro-governance" in social governance.

From the practical level, this study starts with exploring the influence factors of village cadres on the standardized management system of village affairs, which is influenced and restricted by many factors, which leads to the deviation of the implementation effect from the expectation. In order to achieve the expected effect, a system needs to be improved and perfected continuously. The research puts forward policy suggestions from the analysis of the influencing factors of the system, which provides a certain reference for safeguarding the legitimate rights of farmers and improving the level of rule of law in rural governance. Interview with villagers and village cadres, investigate villagers and village cadres' evaluation of the standardized management system of village affairs, deepen villager cadres cognition of the standardized management system of village affairs, supervise village cadres' implementation of the standardized management system of village affairs, Truly implement this system into rural practice.

However, due to the limitation of the actual situation, this study has a certain degree of one-sidedness in selecting only one area, but it should also be seen that, although the L District of Y City, Shandong Province selected in this study has its own particularities. In general, it reflects the general practical problems faced by the implementation of the current standardized management system of village-level affairs. There is no system that is successful once. Problems are discovered from practice, and they are corrected in time, and the system is constantly supplemented and perfected to form a virtuous circle.

\section{References}

$\mathrm{Pu}, \mathrm{S}$., \& Sun, W. Y. (2018). Research on rural talent construction policy under the background of implementing rural revitalization strategy. Chinese Administration, (11), 90-93. 
Sun, Q. H. (2017). Small and Micro Power List: Village Governance in the Transformation from Weak Rules to Strong Rules-An Investigation of the Power List System of Village Level in N County, Zhejiang Province. Henan Social Sciences, 25(10), 58-62.

Tian, H. (2017). Build the first "anti-corruption wall" in rural areas. Leadership Science, (06), 45.

Wang, S. (2020). Research on the involution of village cadres' practical power under the strategy of rural revitalization-Based on the field discoveries of Luzhonggu Town. Leadership Science, (21), 105-108.

Yu, Y. J., \& Chen, W. Q. (2018). Theoretical logic, realistic dilemma and effective path to control "microcorruption". Chinese Administration, (09), 105-110.

\section{Copyrights}

Copyright for this article is retained by the author(s), with first publication rights granted to the journal.

This is an open-access article distributed under the terms and conditions of the Creative Commons Attribution license (http://creativecommons.org/licenses/by/4.0/). 